\title{
RELIGIOUS MODERATION IN KARAPASAN THE LOCAL CULTURE OF TANA TORAJA COMMUNITY IN SOUTH SULAWESI
}

\author{
Faizal Bachrong \\ Balai Penelitian dan Pengembangan Agama Makassar \\ Jl. AP. Pettarani 72 Makassar \\ Email: faizalbachrong59@gmail.com
}

Fithrah Auliya Ansar

UIN Raden Intan Lampung

Jln. Endro Suratmin, Sukarame 3513, Bandar Lampung

Email: Fitrahauliyaansar@radenintan.ac.id

Article received February $8^{\text {th }}, 2021$; Article revised April $3^{\text {th }}, 2021$; Article approved May $8^{\text {th }}, 2021$

\begin{abstract}
This study aims to find out the religious moderation oriented on local wisdom in the local community, the function of local wisdom in establishing a religious moderation climate, and local wisdom development strategies that contain elements of religious moderation that can be implemented in the policy. This study used descriptive research to explore the local wisdom in the developing community which interrelated with religious moderation. The study was conducted in Tana Toraja Regency, South Sulawesi Province. The data were collected through in-depth interviews with informants, document study, and field observations. The data collected then analyzed in the writing stage and were analyzed when being reduced, then were presented in the form of a description. The results of this study indicated as follows: (1) the religious moderation oriented local wisdom contained in the local community are Aluk Tondolo and the Tongkonan traditional house as parts of the culture and local wisdom of Tana Toraja, (2) The Tongkonan traditional house is a symbol of harmony and kinship which contains some local wisdom, including the Rambu Solo, Rambu Tuka and Karapasan ceremonies, in which the Karapasan Culture is believed by its adherents or the Toraja tribe to be a path towards peace, (3) The moderation of life with ambiance of harmony between religious communities has gone very well since the Toraja people know harmonious life between 2 (two) or more different religions.
\end{abstract}

Keywords: religious moderation, local culture, religious harmony

\section{INTRODUCTION}

$\mathrm{R}$ eligious moderation oriented in harmonious life is the foundation of the Indonesian nation. Without a willingness to live in harmony, there will be a threat of disintegration into Indonesian society. Therefore, Indonesia consists of various social, religious and cultural identities based on oral tradition. Oral tradition is conceptually an inseparable part of the local wisdom of the community, which contains the collective memory of the community on culture and the wisdom of life comprehensively that has been inherited from generation to generation. This is expected to be a means of moderation, especially for the development and practice of more tolerant religious teachings. In addition, it contains advice on religion-based social solidarity to avoid the religious conflicts.

The unique traditions in Indonesia, in all regions, always highlight community or togetherness in its meanings and implementation (Muslim, 2016: 259-274). One kind of cultural expression is an oral tradition, or in another term used by Danandjadja (1997: 22 and 153), oral folklore, or partial oral. In fact, oral traditions are also very dynamic following the development of the supporting communities and provide new solutions and discourses in any era. This is what makes the oral tradition an inseparable part of the concept of moderation in society, both in relation to strengthening social solidarity in general, and in the development and embodiment of oral traditions in the context of promoting religious moderation. 
Oral tradition itself is very similar to several factors, namely (1) spending the free time, (2) expressing views and attitudes, (3) imagining group illusions, (4) as a mandate for the next generation, and (5) life determination due to its social rules as the way of life. The identification of moderation in religious understanding will then be carried out at least on these five factors, which include various aspects, namely, history, moral values, religion, customs, proverbs, songs, and mantras. Oral tradition functions as follows; (1) a protection system, as a shadow of the illusion of a collective society, (2) a means of ratifying cultural regulations and institutions, (3) an educational tool for children, and (4) a means of enforcement/supervisor regarding the adherence to social values and norms.

All these factors are the focus of the study to observe and find out the elements of moderation that are inherited and connected in people's daily lives. In order to avoid the extinction of this very valuable heritage, which has a function as a source of knowledge as well as a source of identity formation in the development of world culture, rare items such as oral traditions are objects that deserve to be researched, documented and managed collectively through an approach that is has been in accordance with the nature of the oral tradition or according to modern needs. The results of the research are believed to be able to show concern and respect for the academic community and also the government for their cultural heritage, and can produce more useful findings and input for many related parties (Pudentia, 2014: 5).

Attention to religious aspects in a particular cultural form (religious reception in culture), including oral tradition, is important because changes and movements in society in various places often occur as a result of the introduction of a new religion and belief system in the concerned community (Sedyawati, 2014: 467). The same thing is also stated by Zoetmulder (2007: 327), that the understanding of the peaks or forms of culture cannot be achieved properly without understanding religious teachings, values, or ideas behind which permeates within and shape the culture.

Therefore, the research with an idea of internalizing the values of oral traditions that are still alive in community in order to develop religious moderation values is important by targeting institutions and communities that support the strengthening of the oral tradition as an important part of cultural wisdom that is manifested in daily life.

In Eastern Indonesia, there are many cultural systems that are used as one of the main approaches in order to build harmony. The system is then embodied in local institutions that support harmony such as sipakatau sipakalabbi (humanize each other, respect each other) in South Sulawesi, "pela gandong, kapata, jugulu-jugulu, pantong, ale rasa beta rasa torang samua basudara" Institutions in Maluku, "dapo moa-moa sioho (love each other), dapo angka angkatau (honor each other), dapo mo moologho (help each other), dapo adha adhati (respect each other), dan dapo pia piara/ dapo bhini-bhini kuli (teach, love, and take care of each other)" in Southeast Sulawesi, and many other values that can be explored deeper and be emphasized as the tools to achieve harmonious life. All of these institutions are articulated in every cultural and community governance which invites people to make peace. (Saprillah, 2014) (Sabara, 2014: 14) (Muslim, 2016: 221-230).

Therefore, in order to prepare policy materials in the field of religious treasures related to oral traditions, especially for those related to religious moderation which requires the fulfillment of the main elements of the Strategic Plan of the Research and Development Agency and Religious Education and Training of the Ministry of Religion of the Republic of Indonesia, namely the creation of harmony between religious communities, there is a need of further investigation related to the values in the oral tradition that has the potential to "invite" people to always live in the context of moderation. At the same time exploration pockets of peace based on locality which as far as possible can become the basis of the main supporting movement for religious moderation which is expected to stimulate the growth and development of community groups that want peace.

Based on the background, it is known that further research is needed which is integrated into the main problem; how local wisdom in society functions as a means of 
religious moderation in Eastern Indonesia. The subject was then revealed in the research questions as follows: 1 . Which local wisdom in Tana Toraja community that is oriented towards religious moderation? 2. How do local wisdoms function in creating a climate of religious moderation? 3. How can the local wisdom development strategy that contains elements of religious moderation be implemented in the policy?

This study aims to find out how local wisdom in society functions as a means of religious moderation in Eastern Indonesia. The specific objectives of this study are: a. to find out the religious moderation oriented local wisdom of Tana Toraja community, b. to find out the function of local wisdom in creating a climate of religious moderation, c. to find out the local wisdom development strategy containing elements of religious moderation can be implemented in policy. The uses of this research are: a. Become a policy material for the government in creating religious moderation imbued with local cultural wisdom embedded in the community b. As an academic reference for other research $\mathrm{c}$. Furthermore, for the internal and external sides of the Makassar Religious Research and Development Agency.

\section{LITERATURE REVIEW}

Lektur conducted the latest research, a field of Organizational Management and Religious Treasure of Makassar Research and Development Agency of Religion in 2019 with the theme of Religious Moderation of Oral Traditions in Community carried out in four provinces, namely Maluku, South Sulawesi, East Kalimantan and Southeast Sulawesi. This study initiated a recommendation that the oral tradition understood by the local community is able to maintain harmony between religions since it uses local languages that can touch the hearts of its speakers and audiences (Muslim, et.al, 2019).

The latest article by Idham entitled Moderation in Islamic Culture highlights the problem of Moderation of Islam in Indonesia in the last 20 years has sparked many questions nationally and internationally. They question how Islam in Indonesia, which is well-known for its friendly nature for hundreds of years, suddenly changes into fierceness, as exemplified by the presence of terrorists and Muslims intolerant with other religious groups and even with other Muslims? Islamic moderation became his attention in the speech. It is these moderate Muslim attitudes that shape a peaceful Indonesia within a diversity of religions. On the other hand, the loss of moderate attitude can create clashes among the people of Indonesia.

The Makassar Research and Development Agency of Religion in 2016 has conducted research with the theme of Preserving Religious Harmony Based on Local Wisdom. The research was conducted in 3 regions, namely North Sulawesi, West Papua and Kendari City. The results showed that local wisdom remained internalized and institutionalized in community institutions and could function as a tool and a means for the preservation of adherence to religious harmony through the philosophy of Torang Samua Basudara (we are all brothers and sisters) (Muslim, 2016: 109-122), Kalosara, and many others. Furthermore, the research recommended looking further into the institutionalized and more on the technical concept of religious moderation in the oral tradition of community to make it more operational.

The book by M. Quraish Shihab entitled "Wasathiyyah (Moderation in Islam) of the Insights of Islam on Religious Moderation" showed that the issue of moderation or Wasathiyyah is neither a dubious attitude towards something, like being neutral or passive, or mathematical neutrality, nor something that is suggested by the word "wasath", meaning "middle", which conveys the view that this wasathiyyah does not encourage people to try to reach the top of something good and positive such as worship, knowledge, wealth and others.

\section{RESEARCH METHOD}

This study used qualitative descriptive research method by exploring local wisdom in developing communities that are interrelated with religious moderation. The exploration and extraction of local wisdom were made to build harmony amid differences and balance in society. The analysis was expected after taking an inventory of the meanings of local wisdom that contain religious moderation that is believed and is still carried out by the community (traditional leaders, religious 
leaders, cultural observers, scientists who observe local values and norms, etc.), so that the results of interviews were not simply used as a single tool in data analysis. However, a theoretical expansion with the values and norms of religious moderation remained needed. The data were collected through indepth interviews with informants, document study, and field observations. This study was conducted in Tana Toraja, South Sulawesi.

\section{DISCUSSION}

Tana Toraja regency is located in $119^{\circ}$ - $120^{\circ}$ East Longitude and $2^{\circ}-3^{\circ}$ South Latitude, with an area of $3,203 \mathrm{~km}^{2}$, before the expansion. Makale City is the capital city of Tana Toraja, which is known as a cool and comfortable weather, separated by one of the largest rivers in South Sulawesi, namely the Sa'dan River, which is one of the power plant sources in South Sulawesi.

Tana Toraja borders with North Toraja Regency and West Sulawesi Province. In the Northern part, with Enrekang and Pinrang Regencies while in the Southern part, with Luwu Regency in the Eastern part. Also by West Sulawesi Province in the Western Part.

Makale City, the capital of Tana Toraja Regency, is located about $329 \mathrm{~km}$ away from the Northern part of Makassar City, the capital city of South Sulawesi Province, with an 8-hour trip, which crosses through several cities, namely Pangkep Regency, Sidrap Regency, Enrekang Regency, Barru Regency, Pare-pare City and Maros Regency. In South Sulawesi Province, Tana Toraja Regency is also known as a cultural and tourism icon which makes the tourism industry in Indonesia puts it as a tourism destination. In this regard, it can also increase the growth of various production and economic activities in Tana Toraja Regency.

Tana Toraja has a quite wide area, so that there was a discourse to expand the territory and to divide the Tana Toraja community into 2 as a result of the expansion. In 2018, a new regency was established based on law number 28 of 2018, namely North Toraja Regency. Thus, Toraja, which had 15 sub-districts previously would have 40 subdistricts after the official expansion. A total of 21 sub-districts are included in the territory of North Toraja, and the remaining 19 sub- districts are in the territory of Tana Toraja Regency.

According to Central Bureau of Statistics, Tana Toraja and North Toraja Regencies had a population as follows (Central Bureau of Statistics of South Sulawesi, 2019). Tana Toraja Regency Total: 232.821 people (Male: 117.573 people, and Female: 115.248, people). East Toraja Regency Total: 229.798, people (Male: 115.086 people and Female: 114.712 people). According to the Central Bureau of Statistics, most of the people Tana Toraja and North Toraja Regencies in 2019 adhered to Protestant Christianity (Central Bureau of Statistics of South Sulawesi, 2019). The details of the number and percentage of Religion are as follows: Moslem: 54.485. people: $12,76, \%$, Christian: 355.904 . people: 64,74,\%, Catholic: 100.064 people: $18,68, \%$, Buddhism: 21.621. people: 0,01,\%, Hindu: 1.728. people: $3,81, \%$, Confucianism: $0,01, \%$, Others: 0,03,\% (Statistics Agency of Tana Toraja \& South Sulawesi, 2019). The availability of places of worship in Toraja Regency can be seen in the following statistics: Mosque: 184, Musalla: 4, Catholic Church: 275. Temple: 0, Protestant Church: 1.275, Vihāra: 0.

\section{Toraja in Historical Frame}

Diversity Article 29 of the 1945 Constitution regulates the religious life in Indonesia, as it has also been regulated in the first principle of Pancasila, which guarantees the freedom of every citizen to adhere to a religion and carry out worship in accordance with their respective religions and beliefs. The purpose of preserving religious life is to create a harmonious, equal and peaceful community life to overcome various kinds of problems and disrupting and obstructing socio-cultural impacts for the development of a nation in this era of globalization.

Many opinions emerge from the people regarding the origin of the name Toraja. First, according to the Bugis-Sidenreng people, it derived from the words "to riajang" which means "people who are meditating in highlands or mountains". Second, according to Luwu people, since the Dutch era, it derived from the words "to riajang" which means "the people who are meditating on the western side". Besides, there are also other opinions 
that state the name Toraja derived from the word "Toraya", derived from the word "tau/to" which means "people" and the word "raya", a derivative word of "marau", which means "great". Thus, it cannot be denied that the word Toraya means the great or aristocratic people. Based on the the myths of the community, Toraya was an autonomous state in the past. Its original name was Tondok Lepongan Bulan or Tana Matarik Allo which means a state in the form of government and united community, like the moon and sun for its rounded shape.

There was also another myth from the aristocrats saying that Toraja derived from the words "tau raja" meaning "the king or king's descendant". The aristocrats of Toraja (tana'bulan) also thought they were the descendants of gods from heaven. Their first ancestor was the descendant or incarnation of Puang Matua (God/Supreme God) who later became the king on Earth (Tondok Lepongan Bulan or Tana Matarik Allo). Until now, this myth is still justified and adhered to when there is a marriage between aristocrats (tana'bulan).

Tonkin Bay is actually the origin of Toraja people. The bay is located between South China and North Vietnam. According to the Toraja people, this is their area of origin. It started when immigrants inhabited the coastal areas of Sulawesi. Then, they moved to the higher land, which now becomes their homeland. The inhabitants of Tana Toraja are a manifestation of the process of mixing cultures between the natives or local people who live in the highlands in the Sulawesi region with immigrants from Tonkin Yunnan Bay, South China. The mixing of the two groups of people started as a large number of immigrants came from the Indochina region around the upstream river, around Enrekang area. Furthermore, the immigrants established a residence in the area.

Most of the inhabitants of Tana Toraja adhere to traditional ritual systems and beliefs that have been passed from their predecessors or ancestors. The traditional Torajan belief system is polytheistic animism, called aluk or "jalan/path", a belief that recognizes the existence of or worships more than one God (multiple gods). To this day, most of Toraja population is Protestants, followed by Catholics, and Muslims at the least. Yet, this situation does not cause conflicts among them, instead making their lives harmonious and peaceful.

The trust of the people of Tana Toraja is the result of the arrival of the Dutch to Indonesia. About the 17th century, the Dutch came and controlled the trade and politics on the island of Sulawesi through the Vereenigde Oost-Indische Compagnie (VOC). Even though the Dutch were already on the island of Selebes, especially in South Sulawesi in the 17th century, they arrived in Toraja in about 1905. It is estimated that for two centuries, they did not pay attention to or make Toraja as the priority due to its highland location. This situation makes the Toraja people isolated, and this was likely one of the reasons or explanations for why the Toraja people could maintain their traditions and culture.

\section{Tana Toraja Tradition and Culture}

It is a miracle that a local tradition or culture is a treasure which contains various kinds of local wisdom, cultural values, and policies that are revealed in folklore, exhibition art, and various traditions in traditional ceremonies. This tradition or cultural heritage is the wealth of Indonesian culture that we should preserve as it has many cultural identities, as well as cultural origins which are known as Indonesian culture.

Having a discussion about Toraja has its own uniqueness as it is located on a highland with cool weather compared to other areas in South Sulawesi. Apart from the uniqueness of the shape of the house, Toraja also has its own way of preserving its tradition. One of the customs and traditions is the funeral ceremony for the corpse. This funeral ritual ceremony is called as rambu solo. This funeral ceremony can be very festive depending the economic factors, means that the richer and more powerful a person, the more festive the funeral ceremony will be.

Toraja Regency has a culture or tradition in its own way of perserving its culture so that the Toraja people are harmonious, living peacefully and avoiding conflicts between ethnics and religions. The original culture that is still held by this tribe becomes a tourism attraction. Since this tribe has its own privileges, it can be said that the culture is quite rare and unique. The mystical 
nuance attached to this tribe makes a special characteristic that is different from the others.

There have been many discussions or books published recently which contain cultural values and characteristics of Tana Toraja. Tana Toraja tribe is the natives of Toraja that lives in Toraja until now. A tribe that lives in the mountains of the North of South Sulawesi, Indonesia, now has a population of 1 million. Some of them embrace the Aluk To Dolo belief, which is known to be part of the Hindu Dharma Religion. Almost all people celebrate their happiness in celebrating their birthday. However, there are differences with the tribe in Tana Toraja, where this tribe highly appreciates the ritual of death or commonly referred to as a funeral ceremony as a sign of honor to the person who has passed away. The ritual is usually attended by hundreds of people and the event can be held for several days.

\section{Peace on the Land above the Sky}

In general, the Religious Harmony Index in the South Sulawesi region in 2019 was around $75.70 \%$. This figure was above the average national presentation of $73.83 \%$. The results of this index were released by Research and Development Agency for Religious Community Guidance and Services, Research and Development Agency of Religion of the Republic of Indonesia. One of the indicators is the cultural values of local wisdom; sipakatau, sipakainge, sipakalebbi. These values are highly respected by the tribes in South Sulawesi, which consist of Bugis, Makassar, Toraja and Mandar. Those values are talked in their respective local languages, yet, with a similar goal that is to achieve peace and harmony.

Tolerance between religious communities in Toraja and North Toraja regencies is considered to have been running well, as revealed by the Head of the Christian Community Development Committee. Accompanying the Head of Administration Division of the Ministry of Religion of Tana Toraja (H. Arifuddin), The Ministry of Religion of Toraja, Mr. Manta Tato states that the active role of community and religious organization leaders is very important to encourage tolerance between religious communities so that harmony and peace can run smoothly. The existing differences should not be used as a basis for hurting the feelings of others, but these must be managed properly, so that these can be the strength to build and maintain religious tolerance resulting in harmony to be realized in the community.

The harmony between religious communities in Toraja, South Sulawesi Province, is very well maintained, so that peace and security are created and the roles and obligations of the government, as well as the involvement of religious, traditional and community leaders are very important and strong to maintain and settle conflicts in a multi-ethnic and multicultural community situation. Any social conflicts is quickly and easily settled in various ways, including through a cultural approaches, one of which is the traditional Karapas kinship, or in other words, meetings. Karapasan is a spot in Tongkonan traditional house where all problems are discussed.

The Moderation Values of Karapasan in the Local Wisdom in Tongkonan

The culture or tradition of karapasan is called rapaa in Toraja which means meeting, or can also be interpreted as Tudang Sibulung. In this case, it is a symbol or place where religious leaders, traditional leaders, kale banua (part of a house), sit and discuss together and become the basis for a strong adhesive of tolerance between religious communities in Toraja community. In the Tongkonan traditional house, there is a symbol of local wisdom, namely Karapasan. There is a real form where the togetherness and atmosphere of togetherness grows and is maintained, and the spirit of kinship and compassion leads to a form of life with religious harmony nuances among the Toraja ethnic community.

In today's life, there are numerous problems that we have to face, as faced by the Torajan ethnic community, and one way to solve it is through deliberation, in this case, religion and culture. The Toraja ethnic community has a symbol of local religious traditions, one of which is Karapas, in which any problem will be discussed in the Tongkonan traditional house (karapas) and settled peacefully. One of the cases often faced by the Toraja ethnic community is the issue of customary land ownership of Tongkonan. We all know that land ownership conflict/dispute 
occurs everywhere. The Toraja ethnic community does not necessarily take the case to the legal/court regulations in settling disputes/conflicts but through deliberation in the karapas culture, called hakim adat pendamai (the customary peace judges). The judges consist of traditional leaders and community leaders who know the history of the land ownership in the area. The judges are proposed by the community and appointed by the government.

As stated by Pastor Daud Sangka Palisungan that settling the disputes through the court is only to judge who win or lose the disputes and may result in conflict among family members. Thus, karapas can be a filter for such conflict/dispute, because the Toraja ethnic community prioritizes RARABUKU (family relationship and kinship).

The religious and traditional leader in Tana Toraja, Pastor Daud Sangka Palisungan, the Head of Toraja Church Advisory Council, stated that regardless the religion, the Toraja community upholds the symbol of Aluk Tadolo. According to him, the characteristic or original identity of Toraja is based on Aluk Todolo, but due to the recent development era, the influence is very strong so that this tradition has begun to fade or is no longer dominant. Nonetheless, in the life of the Toraja people, Alukta cannot just disappear. The presence of Alukta which is no less important than the customs that apply in Toraja, Toraja and Aluk Customs is a unity that is both interrelated and inseparable. Aluk is the source of Adat (the customs). Aluk and Adat are thus very influential in the cultural harmonization relationship between families in Tongkonan traditional houses. Furthermore, based on the interview conducted with Mr. Daud Sangka Palisungan, in the tradition aluk rambu solo ceremony which is carried out by the Toraja people, it is currently undergoing significant changes, especially for sesaji (offerings for god). One of the factors driving this change is financial factor, because the sacrificial animals usually come at a fairly high price. It is a special species of buffalo used in the ceremony, a white buffalo (tedong bonga) which costs around 10 to 50 million rupiahs each.

This was also confirmed by Pastor Elvis Saladon, a lecturer of the Christian
University of Indonesia and cultural figure of Tana Toraja, that the religious tolerance in Toraja ends in Tongkonan (Toraja traditional house), because that is the center of all cultural activities, whether in the form of a funeral ceremony (rambu solo), thanksgiving ceremony (rambu tuka), and other ceremonies. All of these ceremonies are called Karapas (meetings). Karapas is a tradition of building kinship and harmony in which all aspects of life are discussed and decided on in the Tongkonan house. Tongkonan is a symbol of alliance, where the family talks in a place called karapas about anything wants to carry out for, both Muslim and other religion people/families. One example given by Pastor Elvis was Mangarimu. It is an event when there is a plan to build a tongkonan house in which all the extended families gathered regardless their economic capacity, for both the rich and the poor, and for any religion, they are all gathered to build a Tongkonan house collectively. After the process of constructing a traditional tongkonan house is completed, the entire extended family is gathered again to hold a thanksgiving ceremony upon the completion of the construction of the Tongkonan house. All of them are obliged to come, including those who live outside the region, so that everyone knows each other as they are one family with multiple religions, both Muslims, Christians and other religions, all of them gathered in the tongkonan house, called as karapas. Karapas is also part of the life principles of the Tana Toraja tribe. which is called saksarekan which means brothers. Thus, the values of tolerance and kinship of the Tana Toraja tribe are contained in the Tongkonan house and Karapasan, that is what makes peace throughout the ages.

Exploring the meaning of cultural and religious symbols in a broad context for the benefit of humans that are continuously encouraged by the community, either by the government, religious leaders, or traditional leaders. Mr. Pongtandi, the Secretary of the Toraja Cultural Service, stated that Tongkonan house contains the value of tolerance which makes Toraja tribe to be not easily provoked by conflicts or disharmony between religious communities that often erupt in a number of areas in the country. Furthermore, he conveyed that the synergy that has been built between 
ethnicities, tribes and religious communities in Toraja has been going on hundreds of years. Interestingly, according to him, the Toraja people in enriching their awareness of tolerance not only utilize their respective religions as a base, but also Toraja culture which is passed down from generation to generation. That is the very tolerant side of Toraja tribe.

Tolerance between Toraja community members was very well-established and strong during the ethnicity, religion, and race conflict occurred in Luwu in 1998. The Toraja people who come from various religions and tribes have played a role in resolving the conflict. $\mathrm{Mr}$. Poktangi said that during the ethnicity, religion, and race conflict in Luwu 1998, the Torajan people were also called to play a role in helping resolve the conflict, as they come from various religions and tribes. We are grateful that the conflict has been resolved, and it did not spread to other areas, including our area in Toraja.

Mr. Marcus Taraklinggi, the Head of Cultural Section of The Cultural Affair Office of Toraja as well as the observer of the Tana Toraja tribe culture said that the people of Tana Toraja are multicultural. For example, there are some parents are Christian but their children convert to Islam because they embrace the same religion of their spouses. Even in the management of family identity cards, there are some cases of having 3 different religions in one family identity card. Furthermore, he said that in the process of the ceremony, both in rambu solo, rambu tuka, and other ceremonies, we all gather in the ceremonies. For example, in the funeral ceremony, rambu solo, we give one or two buffaloes alive from all buffaloes sacrificed for the ceremony, including the white buffaloes (tedong bonga), for the Muslim brothers and sisters to sacrifice and then process or cook the those buffaloes in Islamic ways. When it comes to time to eat, we all gather, eat Together, but with different utensils because we respect our Muslim brothers and sisters, with different methods of sacrificing animals. This culture and tradition preserved for decades since the presence of Islam in Tana Toraja. Thus, tolerance between people has long been running in the Toraja ethnic group because there is local wisdom in the
Tongkonan traditional house and Karapas tradition within (We are brothers and sisters), and there is even an expression that says Misa kanda dipotua pantan kanda dipomate which means united we stand, divided we fall. That is the value of religious moderation in the land above the sky (Toraja).

Kyai H. Ahmad Tiago, Deputy Chairman of Indonesian Council of Ulema and Chairman of Nahdlatul Ulama of Toraja, said that fostering an atmosphere of life for the people of Toraja is based on the spirit of unity and integrity, kinship, togetherness and peace among people. Thus, the harmony or kinship between the people in Toraja is good, even very good. One of the clear proofs that the Toraja people are very tolerant is in the real activities of Muslims at the opening of the 31st Provincial Level Selection of Quran and Hadist Recitation (STQH) in Toraja Regency in 2019. In this event, the decoration of the place and other facilities were supported by the church in Tana Toraja for the event and even for the accommodation for the participants. From which, the colors of diversity and tolerance were very visible, even the Head of STQH committee was a Christian, DR. Yunus Sirante, the Head of the Agency for Regional Development. The value of the religious moderation value of Tana Toraja goes very well, it is because there is a culture in the Tongkonan traditional house in which there is a Karapas tradition which is also called as Tudang Sipulung (meeting), which result in peacefulness.

\section{CLOSING}

Religions and beliefs of the Toraja people, Aluk Tondolo and the Tongkonan traditional house are part of the local culture and wisdom of Toraja. Tongkonan traditional house is a symbol of harmony and kinship with local wisdom within. The moderation of life with nuances of harmony between religious communities has been going very well since the Toraja people know togetherness between 2 (two) or more different religions.

From the findings above, there were several things necessary for policy recommendations and follow-up actions, as follows: (1) The religious leaders and community are recommended to maintain and improve religious life in the area. 
(2) Tongkonan is an ancestral heritage that contains tolerance between people and can be applied when there are intolerant community approaches.

(3) The government, in this case, the Ministry of Religion, is at the forefront to strengthen and maintain tolerance and harmony among the people and makes the essence of religious moderation in local communities such as Tongkonan, karapas, and so on, as the main material for composing the main book of religious moderation, as a comparison and complement of the narratives of moderation from a religious perspective.

\section{ACKNOWLEDGMENT}

The researchers would like to thank the Head of the Religious Research and Development Agency of Makassar for instructing a duty in Toraja Regency. Likewise, the researcher thank DR. Abd Kadir Massoweang, M.Ag. and Prof. Idham Khalid, who has directed and provided guidance step by step sincerely in the research completion process. The researchers also thank all informants who cannot be acknowledged individually for their assistance and participation in the process of field data collection.

\section{REFERENCES}

Ahmad, Rumadi. 2019. Penguatan Moderasi Beragama. Kompas.

Badan Pusat Statistik Sulawesi Selatan (BPS. 2018)

Badan Pusat Statistik Toraja. (BPS. 2018).

Aholiab Watloly. 2016.Edited by Rosa Delima. 3rd ed.Perdamaian Berbasis Adat Orang Basudara

Bachrong, F., Marzuki, F \& Bakhtiar, H.S. 2019. Praktik Pencatatan Ijab Qabul Via Online dalam Proses Akad Nikah Di Makassar. Pusaka, Vol 7 No. 1: 4962.

Dokhi, Mohammad \& Teodora, Hadumaon Siagian Dkk. 2016

Fukuyama.1999.Analisis Kearifan Lokal Ditinjau Dari Keragaman Budaya. Jakarta: Kementerian Pendidikan dan Kebudayaan.

Imarah, Muhammad. 1999. Islam Dan Pluralitas (Perbedaan Dan
Kemajemukan Dalam Bingkai

Persatuan. 1st ed. Jakarta: Gema Insani.

J.Goodman, George Ritzer \& Douglas. 2007.

Teori Sosiologi Modern. 6th ed.

Jakarta: Prenada Media Group.

Kajian pustaka.com/2017/09/. 2017.

"Pengertian-Fungsi- Dimensi-

KearifanLokal.Html.No Title."

Pengertian-Fungsi-Dimensi-Kearifan-

Lokal.Html. 2017.

Komariah, Djam'an Satori \& Aan. 2009.

Metodologi Penelitian Kualitatif.

Edited by Riduwan. 1st ed. Bandung:

Alfabeta.

Kompas, 2019. Arifin, Samsul. Studi Agama;

Perspektif Sosiologi Dan Isu-Isu

Kontemporer. UMM Press.

Maula, M Jadul. 2019. Islam Berkebudayaan

Akar Kearifan Tradisi, Ketatanegaraan,

Dan Kebangsaan. 1st ed. Yogyakarta:

Diandra Creative.

Muslim, A. 2016. Artikulasi Religi SajakSajak Basudara di Maluku. Al-Qalam, 19(2), 221-230.

Muslim, A. 2016. Kitorang Samua Basudara: Bijak Bestari di Bilik Harmoni. Harmoni, 15(2), 109-122.

Muslim, A. 2016. Religious and Cultural Harmonies In The Art Of Masamper. Analisa: Journal of Social Science and Religion, 1(2), 259-274.

Muslim, A., Idham, I., \& Subair, M. 2019. Iko Iko Siala Tangang (Tracing Moderatism of Religious Concept From the Oral Traditions of Bajau). In International Conference on Religion and Education.

Nurdin baturante; Tongkonan dan kerukunan tahun 2019

Rahim. Abd. Rahman. 1995. Mengenal Lebih Dekat Tana Toraja.Kementerian Pendidikan dan Kebudayaan Badan Pengembangan dan Pembinaan Bahasa. Robert, Gurr Ted. "Minorities at Risk: Global View of Etnopolotical Conficcts." Wangsington.

Rudyard, Kipling. 1990. "The Ballad Of East and West" Harold Coward, Derridda End Indian Philosophy. New York: Universitity of New york.

Rumahuru, Yance Zadrak. 2012. Islam Syariah Dan Islam Adat Kinstruksi Identitas Keagamaan Dan Perubahan Sosial Di Kalangan Komunitas Muslim 
Hatuhaha Di Negeri Pelauw. 1st ed. Jakarta: Kementerian Agama RI.

Ruslan, Idrus. 2018. "Dimensi Kearifan Lokal Masyarakat Lampung Sebagai Media Resolusi Konflik.” Kalam 12 (1 Juni).

Shihab, M. Quraish. 2019. Wasathiyyah (Wawasan Islam Tentang Moderasi Beragama. Tangerang: Lentera Hati.

Student, Indonesia.n.d.(Pengertianmenurutpar aahli.Net/Pengertian-KearifanLokalSecara-Umum/Perdamaian.

Sugiyono. 2010. Metode Penelitian Pendidikan (Pendekatan Kualitatif, Kuantitatif, Dan R\&D). Bandung: Alfabeta.

The Great Disruption: Human Nature and The Reconstitution of Social Order. Geetz, Clifford. 2019.

"(Seputariilmu.Com/2019/05/." Masyarakat-Multikut uralMenurutPara-Ahli.Html. 2019.

Tim Penyusun Kementerian Agama. 2019. Moderasi Beragama. 1sted. Jakarta Pusat: Badan Litbang dan Diklat Kementerian Agama RI.
Tim Penyusun Tafsir Tematik Kementerian RI Agama. 2012. Edited by Muchlis M. Hanafi. 1st ed. Jakarta Timur: Moderasi Islam (Tafsir Al-Qur'an Tematik). Lajnah Pentashihan Mushaf Al-Qur'an.

Turner, Bryan s. 2012. Teori Sosial (Dari Klasik Sampai Postmodern). Yogyakarta: Pustaka Pelajar

Wahyudianto. 2011. "Teori Kebijakan.” Eko. Blogspot.Com.

Walzer, Michael. 1997. On Toleration,. London: New Haven and London: Yale University Press

Weni rahayu Tongkonan mahakarya arsitektur tradisional suku toraja ,Kementerian pendidikan dan kebudayaan badan pengembangan dan pembinaan Bahasa.

Yin, Robert K. 1996. Studi Kasus Desain \& Metode. 1st ed. Jakarta: PT Raja Grafindo Persada 